\title{
Ensinando Propriedades Coligativas através do Jogo da Velha: uma proposta de avaliação.
}

\author{
Francisca Georgiana M. do Nascimento (IFAC/MPECIM/UFAC) \\ Ticiana do Rego Costa (MPECIM/UFAC) \\ regiana.tavares@gmail.com \\ ticiana.fisica@gmail.com
}

Palavras-Chave: Ensino de Química, aprendizagem significativa, jogo.

\section{Introdução}

O processo avaliativo não pode ser mais considerado apenas centrado em resultados obtidos por áreas ou matérias, ou de cunho punitivo, seletivo e propedêutico (ZABALA, 1998, p. 195). Precisa ser organizado de maneira processual e acompanhar o pensamento de que a escola é centrada na diversidade de pensamentos e ações e tendo como objetivo a formação integral do aluno, ou seja, precisa ser formativo. Conforme o autor, a avaliação formativa é baseada na observação sistemática e processual, considera as competências e habilidades; ocorre para ajudar a atuação do professor e no crescimento do aluno; é um instrumento educativo que informa sobre o andamento do desenvolvimento do aluno ao longo do processo educacional e construção do conhecimento (Zabala, 1998, p. 200,201). A proposta deste trabalho tem como objetivo apresentar o jogo da velha como ferramenta de avaliação no ensino de Propriedades Coligativas para alunos do 2ำ Ano do Ensino Médio. Este conteúdo, apesar de ser apresentado de forma muito teórico, está, muito relacionado com diversas situações do cotidiano do aluno.

\section{Resultados e Discussão}

Após a aula sobre Propriedade Coligativa, três etapas/passos acontecem: uma onde o professor pede ao aluno que estude o assunto - Propriedades coligativas; ele monta uma lista de questões acerca do tema e a outra em sala de aula, em que os alunos serão divididos em dois grupos. $O$ primeiro grupo a iniciar foi aquele que respondeu à primeira pergunta feita pelo professor. Após a resposta correta, o grupo que iniciou, faz uma pergunta para um membro do outro grupo, caso ele responda corretamente, terá o direito de sentar no tabuleiro que será formado por cadeiras que serão organizadas em filas e colunas $3 \times 3$. Caso o aluno não responda corretamente, quem sentará será o aluno que fez a pergunta, aumentando assim a chance de finalizar a rodada do jogo, assim o jogo continuará até finalizar a rodada. Ao final de cada rodada trocam-se os jogadores de modo que todos participem. Finalizando o jogo da velha, todos terão as perguntas e respostas trabalhadas durante 0 jogo para refletirem sobre o erro e o acerto.

O jogo possibilita, conforme Zabala (1998) e Moreira (2005), uma ferramenta onde o professor passa a ser o mediador do jogo e a atração principal sejam seus alunos e o conteúdo a ser avaliado, desse modo, além do aprendizado se tornar efetivo e mais dinâmico, o aluno é avaliado de maneira mais lúdica. Para que o aluno participe, de maneira mais efetiva, é preciso que os alunos busquem os conhecimentos do assunto e demonstre esse aprendizado através das respostas dadas ao longo do jogo. A avaliação nesse jogo é de forma contínua, onde os alunos não saberão em que momento participarão, uma vez que são escolhidos por outros jogadores aleatoriamente, o professor poderá intervir a medida que alguma pergunta ou resposta estiverem incompletas. Dessa forma, o jogo poderá ser um instrumento de avaliação e/ou revisão.

\section{Conclusōes}

A partir desta proposta desenvolvida, foi possível verificar um maior empenho dos alunos em participar de todos os momentos da aula e na construção deste instrumento de avaliação e/ou verificação de aprendizagem, em Propriedades Coligativas. O Jogo da Velha pode ser considerado uma alternativa viável para o desenvolvimento de uma avaliação significativa onde o aluno é o centro do processo de sua aprendizagem.

\section{Agradecimentos}

À Deus por demonstrar seu amor em todos os momentos e aos familiares pela força e encorajamento constante $e$, aos maridos, por financiar essa oportunidade.

\section{Referências Bibliográficas}

FELTRE, R. Química: Físico-Química. 6. Ed. São Paulo: Moderna, 2004. pp.33-40, 1990.

MOREIRA, Marco Antônio. A teoria da Aprendizagem Significativa de Assube. In: Teorias de Aprendizagem. 2 ed. São Paulo: EPU, 2005. P. 159-173.

WYREPKOWSKI, C. C.; KAFER, G. F.; FREITAS, T.; BESPALHUK, K. J. Aprendizagem sobre propriedades coligativas a partir de uma metodologia diferenciada.

ZABALA, Antoni. A Prática Educativa: Como ensinar. Porto Alegre: Artmed, 1998. 